\title{
The Effect of Corporate Social Responsibility on Profitability: A Study of Bank, Finance and Insurance Companies in Sri Lanka
}

\author{
Piriya Muraleetharan (Corresponding author) \\ Faculty of Management Studies and Commerce, University of Jaffna, Sri Lanka \\ E-mail: piriyamuraleetharan@yahoo.co.in
}

T. Velnamby

Faculty of Management Studies and Commerce, University of Jaffna, Sri Lanka

B. Nimalathasan

Faculty of Management Studies and Commerce, University of Jaffna, Sri Lanka

Received: December 7, 2019 Accepted: January 10, 2020 Published: December 30, 2020

doi: 10.5296/ijafr.v10i4.18127

URL: https://doi.org/10.5296/ijafr.v10i4.18127

\begin{abstract}
The corporate social responsibility is essential depute in all organization. So all organizations think about how to achieved that their organization goals in this way one of the aspects as CSR. In this studies the effect of CSR on Profitability. This study tested by relation and impact supported on correlation and regression analysis. The data used were draw from 20 Bank finance and insurance companies in Sri Lanka. Panel data analysed by Bank finance and insurance companies CSR reports were analysed for the period of 2012 - 2016. The effect show that Corporate social responsibility reporting of the bank finance and insurance companies accrued during that time period. The results of the study also explained that there is a significant impact on profitability of the companies. This study was conducted in a underdeveloped country with various environment, economic and social aspects as compared to developed countries.
\end{abstract}

Keywords: Corporate social responsibility, Economic, Environment, Return on assets, Return on equity 


\section{Macrothink \\ International Journal of Accounting and Financial Reporting \\ ISSN 2162-3082 \\ 2020, Vol. 10, No. 4}

\section{Introduction}

In a different country different researchers appear to have various explanation as to what CSR is. Few of researchers said that CSR is an superior instrument to industry the firm and should therefore be led by activity (Lantos, 2001) or be used to enhance the company's brand (Kurucz et al., 2009).

CSR which is later enclosed in an abstract model called the memorial of CSR (Carroll, 1991). The point of time mentioned the Carrol CSR is made profit and obey the activities.

CSR had to embrace a brimful range of activities of business and community. Some time, CSR explanation considers obey the law regarding of profit making. Organizations should not be only evaluator on economic activities, but also on ethical, legal and discretionary activities. According to Werther and Chandler, (2011) the social responsibilities of business should encompass the evaluation of all four faces that society has of organization any time.

Corporate social responsibility (CSR) value different assessment and evaluation their future financial performance. So expert understand CSR as an authority cost, due to the generality of an agency logic, they make pessimistic present for firms with high CSR valuation. The most analyst to focus on stakeholders and evaluation of weakness and increasing of good recommendation of results. Expert issue more positive present for firms with high CSR valuation.

\section{Research Problem}

Corporate social responsibility reporting is more important to every organizations. Few industry have already answered, either by publishing an isolated report attentiveness their interpersonal state, or by giving some data in their yearly study or on their network position. Based on that different countries argued and developed in their regulation and policy. In Sri Lanka, is adopted very low or no concept and with no prospect to follow global standards, firm in these countries lean not to support to corporate social responsibility (CSR) reports.

CSR its profitability its extended term attainment. The CSR and profitability explained different components in different organizations. In this study is to find the impact of CSR on profitability bank finance and insurance companies in Sri Lanka. The examination has shown that on that point is an ambient contact between CSR and firm's long run profitability. Reported to it, the inquiry question is as follows.

Is there any impact of CSR on profitability of bank finance and insurance companies in Sri Lanka?

\section{Literature Review}

Gray, Kouhy and Lavers (1995) explained that disclosure of social and environmental factors significantly increased from the 1980s to the 1990s.Corporate Social Reporting (CSR) has been formulated to pass the long-standing model of commercial enterprise coverage which importance a company's economical business stipulation. 


\section{MInstitute ${ }_{\text {Imk }}^{\text {Macrothink }}$}

International Journal of Accounting and Financial Reporting

ISSN 2162-3082

2020, Vol. 10, No. 4

Kalisch (2001), disclosed that different CSR in international tour companies in the UK, In direct contrast, idea like property business or accountable tourism, which incorporate the same value as CSR. Which content a tactful choice to collective tourism products without the volition to be an moderately bankable source of financial gain or a correspondent competitory benefit Monshausen \& Fuchs, 2010) and Butler (1999).

Friedman (1970) explained social obligation of business is to change its profits and organization's obligation to appraisal gainful in the power of its workers is part of the overall CSR concept. Business accord on association, such as the improvement of artificial and social resources, of doing concern and effect into the idea of sustainability (Crane \& Matten, 2007).

Elkington; as cited in Crane et al., (2007) explained that sustainability improvement refers to the long-term maintenance of systems according to social, economic and environmental circumstance. It explains the condition of industries not only add efficient value to their commerce interest, but also social and economic value.

Turker (2009) said that CSR, environmental, internal employment, ethical and legal formed From each one feature covers a bound of support, contribution, piece of work life arrangement and situation questions.

Porter and Kramer (2002) said that CSR as a shape of which can be combined with economic benefits to provide a form of matched benefit. Godfrey and Hatch (2006) implied that cultural accountable activity and the wider conception of CSR have no lucid affiliation.

CSR definitions across the decades. One original 1950s definition suggests CSR refers to businessmen in society by Carroll (1999). Wood (1991) defined corporate social execution, a choice subject of CSR, as generalization of social control, policies curriculum and the relation outcomes. It seems both stakeholder association and CSR system in regards to the activity of social announcement and policies; these are related subject of CSR covered by the earlier explanation.

Albinger and Freeman (2000) revealed that employee force is essential along with happiness of employees in regards to organisational activities and diversity as a starring quality for prospective worker.

Kim et al. (2010) concluded that employee-company determination of worker perceived internal to view their provision, the more accessory the outer viewed the system, the more the employee known with it.

\section{Objective of the Study}

In this study one of the main objective is to investigate the impact of CSR on profitability of listed Bank finance and insurance companies during the period of 2012 to 2016.

The secondary objectives are

$>$ To find out the relationship of CSR and Return on Asset.

$>$ To measure the relationship of CSR and Return on Equity. 


\section{MlMacrothink}

International Journal of Accounting and Financial Reporting

ISSN 2162-3082

2020, Vol. 10, No. 4

\section{Methodology}

This study is related with secondary data collection. The researcher collects data from the annual reports of selected companies listed in CSE for the period between 2012 and 2016. The information relating to CSR and FP are collected for the intent of this study. The sources of data include the yearly publications of the CSE, the annual reports and websites of the CSE and the companies. The analysis was done by using the following techniques. Such as Co-efficient of Correlation and regression analysis for the purpose of statistical analyse made by using the Eviews -8 statics software package.

Profitability of the companies is dependent upon the management efficiency. It is represented as follows;

$$
P=f(C S R)
$$

Which shows profitability is the function of management efficiency.

Where;

$$
\mathrm{P}=\text { Profitability }
$$

$\mathrm{CSR}=$ Corporate social responsibility

Here, profitability is measured with the help of two ratios namely Return on Asset, Return on Equity. CSR is measured through index. Therefore, the regression models will be formulated in the following manner;

$$
\begin{aligned}
& \mathrm{ROA}=\beta 0+\beta 1 \mathrm{~A} 1+\beta 2 \mathrm{~A} 2+\beta 3 \mathrm{~A} 3+\mathrm{e}-\text { model } \\
& \mathrm{ROE}=\beta 0+\beta 1 \mathrm{~A} 1+\beta 2 \mathrm{~A} 2+\beta 3 \mathrm{~A} 3+\mathrm{e}-\text { model }
\end{aligned}
$$

Where;

$\mathrm{A} 1=$ Economic

A2= Environmental

A3= Social

ROA $=$ Return on Assets

ROE $=$ Return on Equity

\section{Hypotheses}

H1: There is an impact of CSR on Return on Equity of Listed companies in Sri Lanka.

H2: There is an impact of CSR on Return on Assets of Listed companies in Sri Lanka.

H3: There is relationship between CSR on Profitability of Listed companies in Sri Lanka. 


\section{Presentation and Analysis of Data}

\subsection{Data Analysis}

The process of data analysis consists of understand the relationship between variables such as independent and dependent. The data analysis is important concept for the studies because in this process, the researcher can find out the statistical evidence for prove this study.The following analyses have been done.

\subsection{Correlation Matrix}

The correlation matrix is used to find out the relationship between the independent and dependent variable as per this study relationship between CSR and profitability.

Table 1. Correlation matrix for CSR and profitability

\begin{tabular}{|c|c|c|c|c|c|}
\hline & ROE & $\mathrm{ROA}$ & $\mathrm{ECO}$ & ENVIR & SOCIAL \\
\hline \multirow[t]{2}{*}{ ROE } & 1.000 & & & & \\
\hline & ------------ & & & & \\
\hline \multirow[t]{2}{*}{ ROA } & .846 & 1.000 & & & \\
\hline & 0.000 & ----------- & & & \\
\hline \multirow[t]{2}{*}{ ECO } & 0.145 & 0.245 & 1.000 & & \\
\hline & 0.072 & 0.063 & ---------- & & \\
\hline \multirow[t]{2}{*}{ ENVIR } & 0.354 & 0.245 & 0.054 & 1.000 & \\
\hline & 0.034 & 0.084 & 0.654 & ----------- & \\
\hline \multirow[t]{2}{*}{ SOCIAL } & 0.432 & 0.323 & 0.745 & 0.765 & 1.0000 \\
\hline & 0.012 & 0.072 & 0.000 & 0.000 & ----------- \\
\hline
\end{tabular}

The Table 1 shows the correlation matrix between CSR and profitability. This represents the positive association between the economic environment and social on Return on Asset (ROA) and Return on Equity (ROE). But there is no significant relationship at CSR variables on ROA.

\subsection{Regression Analysis}

The least square regression analysis has been used in this study for the purpose of find out the impact of CSR on profitability.

Table 2. Regression analysis of CSR on return on equity

\begin{tabular}{llclc}
\hline Var & Co eff & Std. Error & T-Sta & P- val \\
\hline C & -3.432 & 16.124 & -0.205 & 0.654 \\
\hline ECO & 9.345 & 15.897 & 0.547 & 0.074 \\
\hline ENVIRON & 13.435 & 17.456 & 0.7 .438 & 0.044 \\
\hline SOCAL & 10.234 & 20.478 & 0.4579 & 0.037 \\
\hline R $^{2}: 0.7846$ & & & & Adj R ${ }^{2}: 0.7645$ \\
F-sta: 2.687 & & & & Pro (F-sta): 0.000 \\
\hline
\end{tabular}

Source: Survey data 


\section{Mll Macrothink}

International Journal of Accounting and Financial Reporting

ISSN 2162-3082

2020, Vol. 10, No. 4

The above table shows the statistical significance impact between the independent variable and dependent variable. The above regression model shows that the Economic, environment social turnover have no significant impact return on Equity of selected bank, finance and insurance companies at level of $5 \%$ significance.

Likewise, the adjusted $\mathrm{R}^{2}$ is viewing that the above mentioned independent variable such as Economic, environment and social have impact on ROE by .7645 . Which mean $76.45 \%$ of the change in the dependent variable can be explained by this model. The $23.55 \%$ change in the dependent variable remains unexplained by the independent variable of this study. The F-statistics is significant because the corresponding $\mathrm{P}$ value shows the $0.0000 \%$ which is less than $5 \%$.

Table 3. Regression analysis of CSR on return on assets

\begin{tabular}{lrrrrr}
\hline Var & Co eff & \multicolumn{2}{c}{ Std. Error } & T-Sta & \multicolumn{2}{c}{ P- val } \\
\hline C & 10.432 & 13.675 & 0.654 & 0.456 \\
\hline ECO & -3.546 & 11.123 & -0.564 & 0.089 \\
\hline ENVIRON & 5.678 & 14.763 & 0.435 & 0.078 \\
\hline SOCAL & -6.769 & 17.452 & -0.432 & 0.057 \\
\hline$R^{2}: 0.8432$ & & & \multicolumn{2}{c}{ Adj R $R^{2}: 0.8234$} \\
F-sta: 10.76 & & & Pro (F-sta): 0.000 \\
\hline
\end{tabular}

According this analysis the statistical significance impact between the CSR variable and financial performance variable. The above regression model shows that CSR variable have not significant impact return on Assets at $5 \%$ of significant level.

Also, the adjusted $\mathrm{R}^{2}$ is showing that CSR and financial performance have impact on ROA by .8432 . Which mean $84.32 \%$ of the change in the dependent variable can be explained by this model. The $15.68 \%$ fluctuation in the dependent variable remains unexplained by the independent variable of this study. The F-statistics is significant because the corresponding $\mathrm{P}$ value shows the 0.0000 which is less than $5 \%$.

The outcome shows a supportive association of CSR and ROA and ROE, which suggest association between CSR activities and profitability of the Companies. These results support the results of Kanwal, et.al (2013) and therefore thirst hypotheses were accepted. This result contradicts the results of Uwalomwa (2011) and Branco and Rodrigues (2008) supports the findings of Kedia and Kuntz (1981) who found a negative correlation between firm CSR and ROA. Regression results convey that significant impact CSR activities on ROE but not ROA. Therefore two hypotheses were partially accepted.

\section{Conclusion}

CSR in underdeveloped countries like Sri Lanka presented herein message readers a conceptual and practical implication of the scheme. For director seeking an executable answer to extend their organization's finance in CSR, the article can work as a able handbook to the many aspects knowing actuation in CSR. For someone concerned in the subject of CSR exercise and expected models, the article present them to a rich field for approaching research. 


\section{MInstitute Macrothink $_{\text {Int }}$}

International Journal of Accounting and Financial Reporting

ISSN 2162-3082

Research in improvement of plan of human action to implement CSR models will be extremely useful in the coming modification of CSR in Sri Lanka.

\section{References}

Albinger, H. S., \& Freeman, S. J. (2000). Corporate social performance and attractiveness as an employer to different job seeking populations. Journal of Business Ethics, 28, 243-54. https://doi.org/10.1023/A:1006289817941

Branco, \& Rodrigues. (2008) Factors Influencing Social Responsibility Disclosure by Portuguese Companies. Journal of Business Ethics, 83, 685-701.

Carroll, A. (1991). The pyramid of corporate social responsibility: toward the moral engagement of organizational stakeholders. Business Horizons, 34(4), 39-48.

Friedman, M. (1962). Capitalism and freedom. University of Chicago Press: Chicago, IL, USA.

Friedman, M. (1970). The Social Responsibility of business is to increase its profits. The New York Times Magazine, September 13.

Godfrey, \& Hatch. (2006, February). Researching Corporate Social Responsibility: An Agenda for the 21st Century. Journal of Business Ethics, 70(1), 87-98. https://doi.org/10.1007/s10551-006-9080-y

Gray, R. H., Bebbington, J., \& Walters, D. (2001). Accounting for the Environment. Sage Publications, Thousand Oaks, CA.

Gray, R., Kouhy, R., \& Lavers, S. (1995). Methodological themes: constructing a research database of social and environmental reporting by UK companies. Auditing \& Accountability Journal, 8(2), 78-101.

Kalisch, A. (2002). Corporate Social Responsibility in the Tourism Industry. Tourism Concern.

Kim, et al.. (201, September). Corporate Social Responsibility and Employee-Company Identification. Journal of Business Ethics, 95(4), 557-569. https://doi.org/10.1007/s10551-010-0440-2

Kurucz, E., Colbert, B., \& Wheeler, D. (2009). The business case for corporate social responsibility. In Crane, A., McWilliams, A., Matten, D., Moon, J., \& Siegel, D. (Eds.), The Oxford Handbook of Corporate Social Responsibility. Oxford University Press, Oxford.

Lantos, G. P. (2001). The boundaries of strategic corporate social responsibility. Journal of Consumer Marketing, 18(2), 595-630.

Monshausen, A., \& Fuchs, H. (2010, March-April). CSR in Tourism: Pretence and Reality. Contours, 20(1), 4-7.

Porter, \& Kramer. (2002, January). The Competitive Advantage of Corporate Philanthropy. Harvard Business Review, 80(12), 56-68. 


\section{Macrothink}

International Journal of Accounting and Financial Reporting ISSN 2162-3082 2020, Vol. 10, No. 4

Turker. (2009, January). Measuring Corporate Social Responsibility: A Scale Development Study. Journal of Business Ethics, 85(4), 411-427.

Uwalomwa. (2011). Corporate Social and Environmental Disclosure in Nigeria: A Comparative Study of the Building Material and Brewery Industry. International Journal of Business and Management, 6(2). https://doi.org/10.5539/ijbm.v6n2p258

Werther, \& Chandler. (2011). Strategic Corporate Responsibility.

\section{Copyright Disclaimer}

Copyright for this article is retained by the author(s), with first publication rights granted to the journal.

This is an open-access article distributed under the terms and conditions of the Creative Commons Attribution license (http://creativecommons.org/licenses/by/4.0/) 